\title{
T-Cell Receptor Gamma Locus
}

National Cancer Institute

\section{Source}

National Cancer Institute. T-Cell Receptor Gamma Locus. NCI Thesaurus. Code C26421.

This region represents the germline organization of the T cell receptor gamma locus.

The gamma locus includes V (variable), J (joining), and C (constant) segments. During T cell development, the gamma chain is synthesized by a recombination event at the DNA level joining a V segment with a J segment. The C segment is later joined by splicing at the RNA level. Recombination of many different $V$ segments with several J seg ments provides a wide range of antigen recognition. Additional diversity is attained by junctional diversity, resulting from the random additional of nucleotides by terminal deoxynucleotidyltransferase. (from LocusLink) 